\section{$\begin{array}{lllllllllll}\mathbf{R} & \mathbf{E} & \mathbf{P} & \mathbf{E} & \mathbf{R} & \mathbf{T} & \mathbf{O} & \mathbf{R} & \mathbf{I} & \mathbf{O}\end{array}$}

Segunda nueva época № 29, Enero-Diciembre, 2019
$\begin{array}{llllllllll}\mathbf{A} & \mathbf{M} & \mathbf{E} & \mathbf{R} & \mathbf{I} & \mathbf{C} & \mathbf{A} & \mathbf{N} & \mathbf{O}\end{array}$

ISSN: 0252-8479 • Doi: 10.15359/ra.1-29.25

\title{
Serie III-Poemas de outono
}

Jose Fabián Elizondo González.

\section{As crianças}

\begin{abstract}
Alguém pode dizer que as crianças não são muito inteligentes, mas então por quê eles sabem qual é o momento quando você precisa um abraço?

o segundo exato quando você não veste a sua armadura?

a palavra precisa para trocar um sorriso fingido por um sorriso que ilumina a vida toda?
\end{abstract}

As crianças não conhecem o que passa por as nossas mentes, mas então por quê eles sabem quando têm que dizer tchauzinho?

quando têm que começar as suas vidas próprias?

quando precisamos duma despedida sem contar as suas luas?

O amor duma criança

é um tesouro

$\mathrm{O}$ amor duma criança

é primitivo

O amor duma criança

é o presente mais merecido. 


\section{A nova estrela}

Já há seis meses que não te vejo.

As folhas das árvores mudaram para você.

Vermelho, laranja, amarelo, marrom

são as cores que abraçam a lembrança do que um dia foi.

As coisas mudam,

mas você tem que saber que nós estamos bem.

As coisas mudam,

mas as estações sempre falam de ti também.

Já há seis meses que não te vejo.

Mas as folhas das árvores não mudaram para mim.

Verde, eu somente vejo verde!

Verde é a única cor que reflete a esperança

que você deixou dentro de mim.

Karolina, você é a minha nova cor.

A cor do futuro.

A cor da certeza,

A cor duma nova estrela. 


\section{Duas estações (polifonia)}

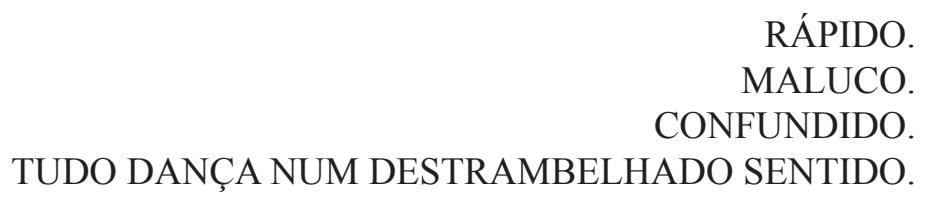

Lento

Sensato

Organizado

Tudo é parte dum impecável aparato.

A GENTE NÃO ENTENDE.

O QUÊ É A “GENTE”?

SÃO ELES QUEM ME TÊM PRESO.

SOU EU "GENTE" TAMBÉM?

SOU EU.

SÃO ELES.

QUEM ME TEM PRESO?

Eu sou a "gente"

Saudável

Judiciosa

(algo) Preconceituosa

Mas não me escute

Você foi preso porque você quis.

O QUÊ É QUE VOCÊ DIZ?

QUEM FALA NESSE ESPELHO

NÃO SOU EU

NÃO É VOCÊ

QUEM É O QUÊ?

Enfermeira,

Você me pode ajudar com o paciente 10 ?

Ele não aceita as suas realidades

Preso

Internado

Encarcerado

Há alguma diferença nas verdades?

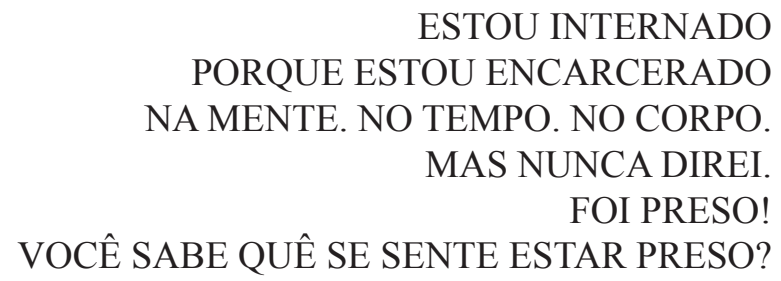

Eu prefiro a medicação. 
